\title{
The Canada Lynx (Lynx canadensis) of Isle Royale: Over-harvest, Climate Change, and the Extirpation of an Island Population
}

\author{
Daniel S. Licht ${ }^{1,5}$, Ron A. Moen ${ }^{2}$, D. Paul Brown ${ }^{3}$, Mark C. Romanski ${ }^{3}$, and Robert A. Gitzen ${ }^{4}$ \\ ${ }^{1}$ National Park Service, 231 East Saint Joseph Street, Rapid City, South Dakota 57701 USA \\ ${ }^{2}$ University of Minnesota, 5013 Miller Trunk Highway, Duluth, Minnesota 55811 USA \\ ${ }^{3}$ Isle Royale National Park, 800 East Lakeshore Drive, Houghton, Michigan 49931 USA \\ ${ }^{4}$ Auburn University, School of Forestry and Wildlife Sciences, Auburn, Alabama 36849 USA \\ ${ }^{5}$ Corresponding author: dan_licht@nps.gov
}

Licht, Daniel S., Ron A. Moen, D. Paul Brown, Mark C. Romanski, and Robert A. Gitzen. 2015. The Canada Lynx (Lynx canadensis) of Isle Royale: over-harvest, climate change, and the extirpation of an island population. Canadian Field-Naturalist 129(2): 139-151.

In the 1930s, the Canada Lynx (Lynx canadensis) was extirpated from Isle Royale, a 535- $\mathrm{km}^{2}$ island located in western Lake Superior, $22 \mathrm{~km}$ from the Ontario and Minnesota shorelines. The first half of the 20th century was a time of change on Isle Royale as Caribou (Rangifer tarandus) disappeared, Coyotes (Canis latrans) briefly appeared, Moose (Alces americanus), Grey Wolves (Canis lupus), and Red Foxes (Vulpes vulpes) became established, and the habitat was altered by fire, logging, and over-browsing. Although these changes may have contributed to the demise of the Canada Lynx, our results suggest that over-harvest was a primary cause. Assuming a peak carrying capacity of 75 Canada Lynx and harvest rates comparable to those reported from 1890-1935, a population viability analysis indicated that the island population had a $0 \%$ chance of surviving 50 years. The analysis also indicated that, even in the absence of harvest, the population had only a $14 \%$ chance of persistence for 250 years. However, when 10 Canada Lynx were added to the modeled population every 10th year, the probability of persistence increased to $100 \%$. Our analyses suggest that the island's Canada Lynx population maintained itself by periodic immigration across an ice bridge; therefore, natural recolonization should be possible. However, the probability of ice-bridge formation has declined from 0.8 in the winter of 1958-59 to 0.1 in 2012-13, likely as a result of climate change. The Isle Royale situation exemplifies another impact of climate change and the possible need to augment populations to mitigate the loss of connectivity.

Key Words: Canada Lynx; Lynx canadensis; climate change; connectivity; island biogeography; Isle Royale; metapopulation; over-harvest; population viability analysis

\section{Introduction}

The historical range of the Canada Lynx (Lynx canadensis) includes Alaska, Canada, and, within the conterminous United States, parts of New England, the upper Midwest, and the Rocky Mountains (McKelvey 2000; Anderson and Lovallo 2003; Poole 2003). In recent times, the distribution of the Canada Lynx has been reduced in the southern portion of its range (Laliberte and Ripple 2004; Koen et al. 2014), mainly due to a combination of over-harvest, loss of suitable habitat, and changes in faunal communities (Ruggiero and McKelvey 2000; United States Fish and Wildlife Service 2000; Anderson and Lovallo 2003). The species is now listed as "threatened" in the conterminous United States under the U.S. Endangered Species Act (Ruggiero and McKelvey 2000; United States Fish and Wildlife Service 2000; Interagency Lynx Biology Team 2013). In Canada, the species is listed as regionally endangered in Nova Scotia and New Brunswick (Mackinnon and Kennedy 2008).

Canada Lynx were present and seemingly abundant on Isle Royale when Europeans explored the island in 1857 (Palliser 1863). Large-scale lynx trapping on Isle Royale apparently started in the 1890s (Martin 1988). Historical records suggest that there was a resident pop- ulation of Canada Lynx on Isle Royale until about the 1930s (Adams 1909; Mech 1966; Johnsson et al. 1982; Martin 1988). Although there have been a few reports of lynx on Isle Royale since then (Johnsson et al. 1982; Martin 1988; Cochrane 1996), there is no evidence of an established breeding population. The island and surrounding islets and waters now constitute Isle Royale National Park, which is managed by the U.S. National Park Service (NPS 1998), whose policies call for restoring extirpated native species when feasible (NPS 2006). A critical step in assessing the feasibility of reintroduction is to determine the cause(s) of the species' extirpation. We reviewed the history of the Canada Lynx on Isle Royale and evaluated possible reasons for extirpation of the species.

\section{Study Area}

Isle Royale is a $535-\mathrm{km}^{2}$ island (about $72 \mathrm{~km} \times 14 \mathrm{~km}$ ) in western Lake Superior, about $22 \mathrm{~km}$ from the Ontario and Minnesota shorelines (Figure 1). It is surrounded by about 400 islets. The island is characterized by short cool summers and long cold winters. Mid-winter snow depths average $44 \mathrm{~cm}$ (Vucetich and Peterson 2011).

Before European settlement, Isle Royale supported an old-growth boreal ecosystem (Cooper 1913; Cole 


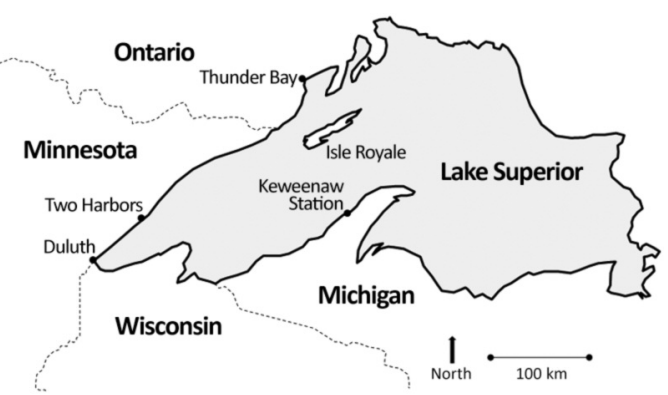

FIgURE 1. Location of Isle Royale.

et al. 1997), with Canada Lynx and Caribou (Rangifer tarandus) as the largest resident wildlife (Adams 1909; Martin 1988; Cochrane 1996). Indigenous people periodically occupied the island for the purposes of hunting, fishing, and copper mining (Shelton 1997). Settlement by people of European descent occurred from the early part of the $19^{\text {th }}$ century to the first half of the $20^{\text {th }}$ century, primarily for the purposes of fishing and copper mining. Fur trapping, mainly American Beaver (Castor canadensis), by European settlers apparently started in the early 19th century (Cochrane 2013), although there is at least one oral history account of a Canada Lynx being trapped in 1873-74 (Cochrane 1996). Significant changes to the island ecosystem occurred in the early 20th century as a result of logging, a large and severe forest fire, and over-browsing by Moose (Alces americanus), which colonized the island in 1900-10 (Murie 1934; Mech 1966). In 1940, Isle Royale National Park was established, and hunting and trapping were prohibited.

The island is currently dominated by a mix of Balsam Fir (Abies balsamea (L.) Miller)-White Spruce (Picea glauca (Moench) Voss)-Trembling Aspen (Populus tremuloides Michaux) and Eastern White Cedar (Thuja occidentalis L.)-Black Spruce (Picea mariana (Miller) Britton, Sterns \& Poggenburgh)-Tamarack (Larix laricina (Du Roi) K. Koch)-Black Ash (Fraxinus nigra Marshall) vegetation types (The Nature Conservancy 1999). The island is recognized for the Grey Wolf (Canis lupus) and Moose populations it supports and the long-term research on their ecology (WolfMoose Project 2013*). The park is designated as an International Biosphere Reserve and $99 \%$ of the island is managed as wilderness under the U.S. Wilderness Act of 1964, which prohibits motorized equipment. There are no permanent human residents and negligible infrastructure.

Canada Lynx are no longer present on Isle Royale. The limited evidence suggests they had a long history of occupation before their extirpation. Cleland (1968) found lynx bone fragments at archeological sites dating back about 2000 years and referred to sites with lynx remains dating back about 600 years (Cleland 1966). In recounting his 1857 visit to Isle Royale, Palliser wrote "the lynx is the largest animal on the island, and is said to be very common" (Palliser 1863: 23). William P. Scott, an early resident of the island, noted the presence of lynx around 1890 (Scott 1925). Martin (1988: 29) wrote that "commercial exploitation of lynxes was underway on the island by 1897." Martin (1988) reported that juvenile lynx were harvested on the island, indicating reproduction and an established population.

A University of Michigan biological study conducted in 1904-05 reported lynx as present, apparently abundant, and distributed over much of the island (Adams 1909). The study also reported that "with the possible exception of the White-footed Mouse (Peromyscus leucopus), the Hare (Lepus americanus) is the most abundant mammal upon Isle Royale" (Adams 1909: 410) and that Red Squirrels (Tamiasciurus hudsonicus) "were exceedingly abundant" (Adams 1909: 399), suggesting high-quality habitat for lynx. Based on these reports, we assume that lynx occupied Isle Royale in pre-Columbian times and were abundant at the time of European settlement. However, sometime in the 1930s they were extirpated from the island (Mech 1966; Johnsson et al. 1982; Martin 1988).

\section{Methods}

We reviewed the scientific and historic literature to identify possible causes for the lynx extirpation. We identified four causes that we critiqued using an inductive qualitative approach; disease, habitat changes, interactions with other predators, and cycles in prey populations. We searched extensively in the peer-reviewed literature for evidence that would support extirpation of Canada Lynx on Isle Royale by each of these possible causes. We summarized results of the literature search qualitatively, and concluded whether there was or was not support for being the cause of extirpation.

Two other potential causes, over-harvest and changes in connectivity, were analyzed quantitatively. Overharvest was analyzed with a population viability analysis, while changes in connectivity between Isle Royale and the mainland were analyzed by searching for evidence of an ice bridge being formed in each winter that data was available.

To better understand the role that harvest played in the extirpation of the Isle Royale lynx population, we conducted a population viability analysis using VORTEX 9.99 (Lacy and Pollak 2014). We used published vital rates (see Anderson and Lovallo 2003; Steury and Murray 2004; Moen et al. 2008), unpublished data from studies in Minnesota (R. Moen, unpublished data), and professional judgement to establish input parameters (Table 1). We conducted sensitivity testing to evaluate and refine model inputs, to identify influential parameters, and to assess the reasonableness of the model (Lacy and Pollak 2014). VORTEX models inbreeding depression using the concept of lethal equivalents whereby 1) new individuals are killed if they have two copies of the same lethal allele, and 2) survival is re- 
TABLE 1. Input parameters used in population viability analysis of Canada Lynx (Lynx canadensis) on Isle Royale. Values following the \pm symbol are the amount of variability at the peak and nadir of the cyclical scenarios.

\begin{tabular}{ll}
\hline \hline Breeding & \\
\hline Adult females breeding at low density & $90 \%$ (SD 5) \\
Adult females breeding at carrying capacity & $50 \%$ (SD 5) \\
Mean no. of mates/successful sire & 1.5 \\
Inbreeding depression & 3.14 \\
Lethal equivalents & $50 \%$ \\
Proportion due to recessive lethal & \\
Reproduction & 2 years \\
Age at first offspring, females and males & 10 years \\
Maximum age of reproduction & 1 \\
Maximum no. litters/year & 6 \\
Maximum no. young/litter & $3.3 \pm 1$ (SD 0.9) \\
Mean no. young/litter & $50: 50$ \\
Sex ratio of young & Yes \\
Environmental variation concordance of reproduction and survival & \\
Annual mortality rate, both sexes & $45 \% \pm 20$ (SD 10) \\
Kitten (age 0-1 year) & $45 \% \pm 20$ (SD 10) \\
Yearling (age 1-2 years) & $10 \% \pm 5$ (SD 5) \\
Adult & 0 \\
Catastrophes & 75 (SD 10) \\
Carrying capacity & Stable age distribution \\
Starting population &
\end{tabular}

Note: $\mathrm{SD}=$ standard deviation.

duced as the inbreeding coefficient increases (Miller and Lacy 2005; Lacy et al. 2014; Lacy and Pollak 2014). We used the VORTEX version 9.99 default default value of 3.14; however, we also ran scenarios assuming no inbreeding depression to better understand the influence of inbreeding on model outputs. We modeled allele frequencies using a single neutral locus and unique alleles for each founder (Lacy et al. 2014). For harvest simulations we ran 1000 iterations for 50 years, i.e., the approximate time frame of the reported lynx harvest at the island. For non-harvest simulations, we initially used 1000 years, but ultimately used 250 years as that period best illustrated the impacts of the various assumptions.

Canada Lynx and their primary prey, Snowshoe Hare, are known to go through an 8-11-year population cycle (Hodges 2000a; Krebs et al. 2001: Figure 2). Historical reports from 1900 to the 1930s suggest that the Isle Royale hare population was cyclical (Martin 1988; Allen 1994) as does more recent fieldwork (Vucetich and Peterson 2011). Therefore, we assumed a cyclical lynx population. We used a 10-year sinusoidal function to mimic the cycle. We varied lynx mortality, litter size, and percentage of females breeding to

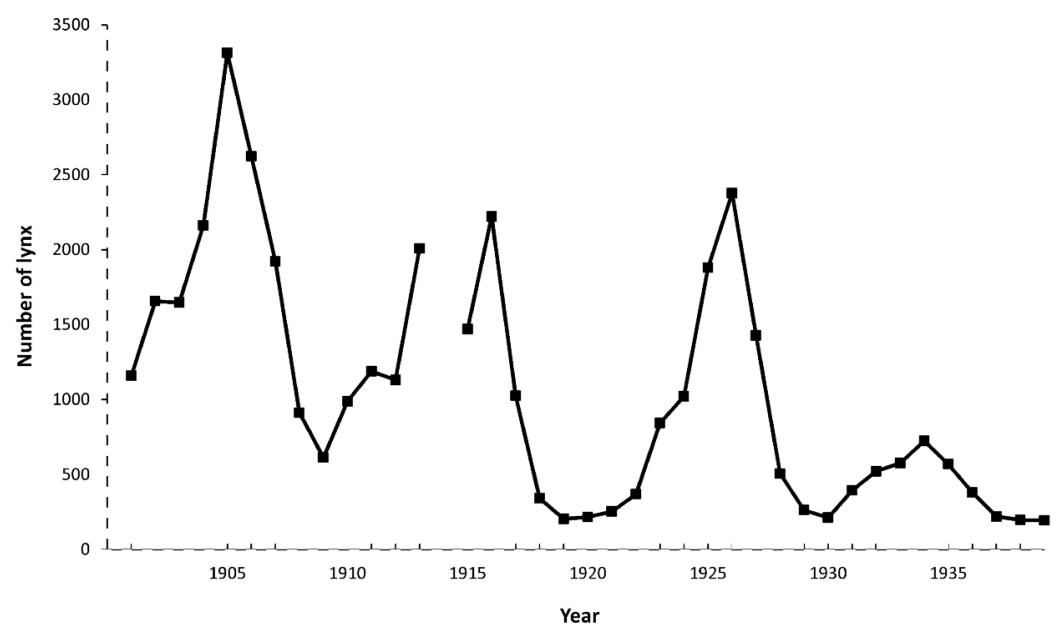

FiguRE 2. Hudson's Bay Company yearly lynx fur returns for the Lakes region (southern Ontario and western Quebec), 1901-39. Source: Elton and Nicholson (1942). 
account for changes between the cycle nadir and peak (Table 1). Our closed cyclical model for Isle Royale resulted in a four-fold increase in lynx abundance from nadir to peak. Our cyclic variability was modest compared with that found in northern regions (Poole 1994; Slough and Mowat 1996); however, amplitudes are believed to be smaller in southern ranges (Hodges 2000b). For example, Slough and Mowat (1996) showed a ninefold change in Snowshoe Hare abundance over a cycle in the Yukon Territory, whereas Vucetich and Peterson (2011) showed only a three- to four-fold change in an index of hare abundance at Isle Royale. There is some evidence that lynx populations in the southern portion of the species range may even be non-cyclical (Hodges 2000b; Murray et al. 2008); however, that may be a recent phenomenon (Poole 2003). Nevertheless, we also ran non-cyclical simulations.

An influential input parameter was carrying capacity. Estimates of Canada Lynx densities in Minnesota and Ontario, and Snowshoe Hare pellet surveys on Isle Royale, suggest that the current peak carrying capacity of the island may be 30-40 lynx (Licht et al. in prep). However, historical lynx harvests at Isle Royale suggest a population substantially greater than that, at least for brief periods, as evidenced by a minimum of 48 lynx harvested in the winter of 1903-04 and 67 in the winter of 1916-17 (Adams 1909; Foster 1917; Mech 1966; Martin 1988). Poole (2003) reviewed the scientific literature and suggested that lynx populations in mature forests in the more southern ranges had peak densities ranging from 8 to 20 per $100 \mathrm{~km}^{2}$ : extrapolating from the mid-point gives a population of 75 lynx for Isle Royale. This peak abundance is plausible based on historical harvests. Therefore, we set carrying capacity at 75 lynx in our baseline model. We also ran simulations with carrying capacities of 38 and 113 lynx; the former approximates the current estimated non-cyclical carrying capacity (D. S. Licht, unpublished data) and the latter approximates the high end reported by Poole (2003).

The historical record from Isle Royale includes harvests of 48 lynx in the winter of 1903-04, 67 lynx in the winter of 1916-17, and over 25 lynx in the early 1930s (Adams 1909; Foster 1917; Mech 1966; Martin 1988). These are likely minimum harvests. For example, the report of 48 lynx captured in 1903-04 was by a father-son combination and primarily from a small portion of the island (Adams 1909). Additional reports of harvests and trapping effort in the 1890-1930s are documented by Martin (1988), Mech (1966), and Cochrane (1996), but little additional quantitative information is available. Cumulatively, the reported harvests appear to have the potential to have extirpated the Isle Royale lynx population. The peak historical harvests in 1903-04 and 1916-17 are 13 years apart with the reported harvest in the early 1930s approximately 14-19 years later (Adams 1909; Foster 1917; Mech 1966; Martin 1988). This periodicity does not synchro- nize with the reported 8-11 year lynx population cycle nor do the reported historical harvests align perfectly with the lynx population peaks for the Lakes region as reported by Elton and Nicholson (1942: Figure 2), creating a conundrum if one assumes the reported large harvests were at population peaks. One possible explanation is that the timing of the population peaks at Isle Royale may have differed from the regional peaks reported by Elton and Nicholson (1942), as lynx population peaks are not synchronous across the species' range (Ranta et al. 1997; Stenseth et al. 1999). Another plausible explanation is that reported harvests did not occur in years when the lynx population peaked. Anderson and Lovallo (2003) stated that lynx harvest rates may be somewhat independent of lynx density and driven more by pelt prices. Furthermore, in a small area, such as Isle Royale, the addition of just a few trappers or trap lines could cause a substantial change in trapping effort, thereby influencing harvest rates more than lynx density. As a result of these unknowns, we ran simulations where harvest peaks and lynx population peaks were asynchronous and other scenarios where harvest and population peaks coincided by assuming a 13-year lynx cycle. We ran simulations that modeled the reported harvests of 48, 67, and more than 25 lynx; simulations that also included 5 or 10 additional lynx harvested each year to account for unreported harvests; and simulations where we removed 50 lynx every $13^{\text {th }}$ year as well as an additional 5 or 10 lynx in the interim years. We did not find useful information regarding the demographic composition of the lynx harvested at Isle Royale; however, others have reported that adult males typically comprise the majority of lynx harvests (Bailey et al. 1986; Quinn and Thompson 1987; Poole 1991). For all harvests, we assumed a composition of $60 \%$ adult male, $30 \%$ adult female, and $10 \%$ kittens split equally between the sexes.

Our initial simulations assumed a closed population. We subsequently posited that lynx might have historically immigrated to Isle Royale every 10 years or so coincident with lynx population peaks farther north. Therefore, we ran simulations that assumed supplementation every $10^{\text {th }}$ year. We altered the default sequence of events in VORTEX so that supplementation (i.e., immigration) occurred before harvest. Carrying-capacity truncation occurred after those events. Henderson (1978) reported about a 12-fold nadir-to-peak increase in lynx harvests in Minnesota from 1940 to the 1970s and Gunderson (1978) reported an eight-fold and two-fold increase in harvested lynx from two sites in Ontario from 1955-58 to 1960-63. We assumed immigration of 10 or 20 adult lynx every $10^{\text {th }}$ year, coinciding with peaks in the resident population: the combination of supplementations and growth of the resident population generally resulted in a five-fold increase from nadir to peak. Although lynx irruptions in Canada sometimes plateau over multiple years (Gunderson 1978), we assumed a single-year influx of im- 
migrants as that approximates what was observed in Minnesota (Mech 1973; Henderson 1978). We assumed a 50:50 sex ratio of the immigrants as reported by Mech (1980) for a recently colonized site in Minnesota. When comparing supplementation and nonsupplementation simulations, we allowed lynx immigration to occur only if there was an extant population at the time of augmentation.

Although lynx can swim and are known to cross cold rivers (Feierabend and Kielland 2014), the farthest distance we know of a lynx swimming is $3.2 \mathrm{~km}$ (Kobalenko 1997); hence, we viewed it as unlikely that immigration occurred via swimming. We thought it more plausible that historical lynx immigration to Isle Royale occurred via an ice bridge between the mainland and the island. In that case, lynx could have recolonized Isle Royale following extirpation, as lynx populations in Minnesota and Ontario have recovered from early-20th-century lows (Poole 2003; Moen et al. 2008). Furthermore, lynx invasions from Ontario into Minnesota have been documented since the 1960s (Mech 1973; Gunderson 1978; Henderson 1978). However, we speculated that a decline in ice-bridge formation in recent decades may have prevented lynx recolonization of Isle Royale. We used three datasets to evaluate a possible decline in ice-bridge formation between the mainland and Isle Royale.

We used National Oceanic and Atmospheric Administration (NOAA), Great Lakes Environmental Research Laboratory ice atlases (Assel et al. 2002; NOAA Great Lakes Environmental Research Laboratory 2014) to calculate the number of days each winter during 1973-2011 that an ice bridge formed between Isle Royale and the mainland. The ice concentration class with the greatest ice surface area and, therefore, the most potential for crossing by lynx, was the $\geq 90 \%$ class. We looked at each daily image and summed the number of days each winter with ice of class $\geq 90 \%$ connecting the mainland to the island. We ran a linear regression of the sum of the days against year. The strength of the dataset is that the data were somewhat systematically collected and the dataset allowed the summation of the total number of days an ice bridge formed each winter. Its weakness is that the iciest class could have as little as $90 \%$ ice cover which may not be enough for a lynx to traverse from the mainland to the island.

Our second analysis of ice-bridge formation used statements from 1965-66 to 2012-13 Isle Royale WolfMoose Project annual reports (Wolf-Moose Project 2013*). Additional data for 1958-59 to 1964-65 and clarification of some ambiguous statements in the annual reports were provided by R. Peterson (personal communication, 2014). For each winter 1958-59 to 2012-13, we assigned either "yes" or "no" for icebridge formation. We then ran a logistic regression on the binomial data. The strength of this dataset is that it better captured true ice-bridge formation that could be traversed by an animal as the primary reason the investigators recorded the observations was for documenting the potential for wolf movement between the mainland and the island. Its weakness is that the total number of days each winter with an ice bridge was not captured, and investigators were only on the island during a portion of the winter (Wolf-Moose Project 2013*).

Our final ice-bridge analysis used 1900-1970 icethickness data collected by the National Weather Service (Assel 2004). We evaluated datasets from the Duluth Harbor, Two Harbors, and Keweenaw Waterway stations (Figure 1); these stations had data for 66 , 44 , and 54 of the years, respectively. We used the annual mean or midpoint of the reported range for each station and regressed that against year. The value of the datasets is that they covered 1900-1970, a period not covered by the other datasets and a time when lynx still occupied Isle Royale. Their weakness is that the data were not collected systematically, the parameter was near-shore ice thickness which might not be strongly correlated to ice surface coverage on the lake, and the stations were a substantial distance from Isle Royale (245 km in the case of Duluth Harbor station).

\section{Results \\ Qualitative evaluation of possible reasons for the extirpation of Canada Lynx}

Disease: Disease can have a catastrophic impact on wildlife, especially small isolated populations (de Castro and Bolker 2005; Cully et al. 2010; Descamps et al. 2012). The anthropogenic introduction of canine parvovirus to Isle Royale in 1981 was probably a factor in a crash of the island's wolf population (Peterson et al. 1998). Therefore, we evaluated disease as a possible cause of the lynx extirpation.

Lynx are susceptible to a variety of diseases, some of which can be lethal (Anderson and Lovallo 2003). Wild et al. (2006) documented Canada Lynx mortality from plague (Yersinia pestis) in Colorado; however, that disease is not known to occur in the Isle Royale region. Ryser-Degiorgis et al. (2005) reported that sarcoptic mange (Sarcoptes scabiei) is the most common infectious cause of death in free-ranging Eurasian Lynx (Lynx lynx), but mange is not known to have occurred at Isle Royale. Vashon et al. (2012) reported lungworm in Canada Lynx in Maine, but only one of 65 animals in that study was reported to have died from disease. In a sample of 215 Canada Lynx, Biek et al. (2002) found a low prevalence of a suite of pathogens. Moen et al. (2008) did not find disease to be a significant mortality factor for Canada Lynx in nearby Minnesota. Likewise, Canada Lynx Conservation and Assessment (Interagency Lynx Biology Team 2013) does not list disease as a high concern in lynx conservation. We know of no evidence of diseasedcaused mortality of Canada Lynx on Isle Royale.

Systemic transitional changes in the vegetation community: The vegetation community on Isle Royale has 
changed dramatically in the past century due primarily to logging, fire, and Moose overabundance (Murie 1934; Mech 1966; Snyder and Janke 1976). Logging and fire can significantly alter habitat; however, depending on the spatial pattern, severity, and return intervals, these disturbances could increase the abundance of lynx by improving conditions for Snowshoe Hare (Parker et al. 1983; Moen et al. 2008; Interagency Lynx Biology Team 2013). At an Ontario study site with 27\% disturbance due to fire, logging, and insect damage, Quinn and Thompson (1987) found that several lynx population parameters were as good as or higher than they were at a site with only $17 \%$ disturbance.

On Isle Royale, over-browsing by Moose might have degraded habitat for Snowshoe Hare. Moose apparently arrived on the island between 1900 and 1910 (Cochrane 2013). The population reached several thousand in the early 1930 s, but then starvation caused a population crash in 1933-35 (Krefting 1974). Murie (1934) reported that Snowshoe Hares were scarce in 1930, and Mech (1966) cited island residents who reported seeing fewer hares in the late 1920s and early 1930s than they had in earlier years; whether these changes were due to systemic habitat alteration or natural oscillations in hare populations is not known. Allen (1994) suggested that Moose overabundance on the island resulted in a decline in Snowshoe Hare numbers that may have contributed to the extirpation of lynx. Conversely, some researchers have reported that forage competition between Moose and Snowshoe Hares is limited because of differences in spatial use and browse heights (Dodds 1960; Oldemeyer 1983); however, the severity of the competition likely depends on the degree of browsing. Although the concurrent timing of the Moose irruption and the lynx extirpation raises the possibility of a cause-and-effect relation, confounding processes may have lessened the impact of Moose over-browsing on the lynx population. A die-off of thousands of Moose (Krefting 1974) would have provided a substantial supply of carrion for lynx that could have mitigated the short-term decline in hare abundance as lynx consume carrion when available and during periods of hare scarcity (Saunders 1963; Brand et al. 1976). Furthermore, the Isle Royale ecosystem includes alternative prey, specifically Red Squirrels (Adams 1909; Johnson 1969), which should have provided an important and relatively stable secondary prey (O’Donoghue et al. 1998) until hare numbers recovered. We suggest that systemic changes in habitat at Isle Royale - primarily related to Moose overabundance - might have contributed to the extirpation of Canada Lynx on the island.

Interactions with other predators: Coyotes appear to have colonized Isle Royale by 1912 (Krefting 1969). In the winter of 1916-17, trappers harvested 60 Coyotes from Isle Royale, but did not extirpate the population (Foster 1917). Cochrane (1996) reported an anonymous 1928 statement that "coyotes are becom- ing so numerous they threaten other wildlife." Lynx apparently disappeared from the island in the 1930s (Mech 1966; Johnsson et al. 1982; Martin 1988), a time when Coyotes were well established. Therefore, it is conceivable that Coyotes were a factor in the extirpation of lynx. Coyotes are suspected of being exploitative or interference competitors of Canada Lynx where their ranges overlap and may be contributing to range contraction and population declines of mainland lynx populations (Buskirk 2000). However, Murray et al. (2008) suggested that the evidence of inter-specific competition between Canada Lynx and Coyotes is weak. According to Cochrane (1996) and Cochrane (2013), Red Foxes (Vulpes vulpes) colonized the island in the 20th century; foxes could have competed with Canada Lynx for Snowshoe Hare and other small prey. However, Johnsson et al. (1982) reported that Red Foxes were scarce until Coyotes were extirpated, which apparently occurred in the 1950s (Mech 1966). The changing mammalian community, especially the presence of Coyotes, may have been a stress on the Canada Lynx population at Isle Royale.

Cyclical collapse in prey populations: The interacting temporal population dynamics of Canada Lynx and Snowshoe Hare are well known (Elton and Nicholson 1942; O'Donoghue et al. 2010), and hare population crashes are typically followed by lynx population crashes (Elton and Nicholson 1942; O'Donoghue et al. 2010). Historical and current evidence suggests that Isle Royale's hare population does oscillate (Martin 1988; Allen 1994; Vucetich and Peterson 2011). When Snowshoe Hare populations in Ontario crash, lynx are thought to emigrate in large numbers to Minnesota (Mech 1973; Gunderson 1978; Henderson 1978). Therefore, lynx could have emigrated from Isle Royale in response to a hare population decline.

However, Isle Royale is immediately east of the Ontario-Minnesota border so it is unclear whether Isle Royale would be a source or recipient of lynx during lows in the Ontario cycle. Furthermore, even if some lynx emigrated from Isle Royale during nadirs in the hare cycle, it is unlikely that all lynx would have left. In northern regions, lynx populations persist even through severe declines in hare populations (Poole 1994; O’Donoghue et al. 1997). Also, Red Squirrels should have provided an important alternative prey for lynx (O’Donoghue et al. 1998). Lynx remains were found on Isle Royale from pre-Columbian times, the species was abundant when the first people of European descent visited the island around 1850, and lynx were common up to the 1930s, suggesting that the population persisted on Isle Royale through numerous hare cycles (Figure 2).

\section{Quantitative analysis of harvest impacts}

Assuming a carrying capacity of 75 Canada Lynx, the reported historical harvests of 48, 67, and 25 animals resulted in a modeled 50 -year population persistence of $15 \%$ (Table 2 ). When the harvest was increased 
TABLE 2. Population viability (50-year) of Canada Lynx (Lynx canadensis) on Isle Royale under reported and assumed historical harvest rates, assuming a peak carrying capacity of 75 lynx.

\begin{tabular}{|c|c|c|c|}
\hline $\begin{array}{l}\text { Harvest } \\
\text { option }\end{array}$ & $\begin{array}{l}\text { Probability of } \\
\text { persistence }\end{array}$ & $\begin{array}{c}\text { Mean no. } \\
\text { years of } \\
\text { extinct runs }\end{array}$ & $\begin{array}{c}\text { Mean final } \\
\text { population size } \\
\text { (extant runs only) }\end{array}$ \\
\hline \multicolumn{4}{|l|}{ Assuming a 10-year population cycle } \\
\hline 48 lynx in year 13,67 in year 26 , and 5/year in years $40-44$ & 0.154 & 19.9 & 35.0 \\
\hline $\begin{array}{l}53 \text { lynx in year } 13,72 \text { in year } 26 \text {, and } 10 / \text { year in years } 40-44 \text {, } \\
\text { plus } 5 \text { in each interim year }\end{array}$ & 0.000 & 17.2 & na \\
\hline \multicolumn{4}{|l|}{ Assuming a 13-year population cycle } \\
\hline 48 lynx in year 13,67 in year 26 , and $5 /$ year in years $40-44$ & 0.278 & 37.8 & 31.5 \\
\hline $\begin{array}{l}53 \text { lynx in year } 13,72 \text { in year } 26 \text {, and } 10 \text { year in years } 40-44 \text {, } \\
\text { plus } 4 \text { in each interim year }\end{array}$ & 0.000 & 19.5 & na \\
\hline
\end{tabular}

Note: na $=$ not applicable.

by five lynx each year, to account for unreported harvest, the probability of persistence was $0 \%$ and the median time to extinction was 15 years. Correlating the reported harvest years with a modeled 13-year lynx cycle increased the probability of persistence to $28 \%$, but, when we assumed an additional five lynx were harvested each year, the probability of persistence was $0 \%$. The only harvest scenarios that produced a greater than $50 \%$ chance of lynx persistence for 50 years were those that assumed a carrying capacity of 113 lynx and/or no lynx harvest in interim years (Figure 3 ).
In non-harvest, 1000-year simulations, all of the cyclical and non-cyclical runs resulted in extinction within 400 years. Therefore, we ran simulations for 250 years and they resulted in a $14 \%$ chance of persistence for a cyclical population and a $42 \%$ chance of persistence for a non-cyclical population (Table 3). When inbreeding was disabled the probability of 250year persistence increased to $100 \%$ for the cyclical scenario (Table 3). Supplementing the island population with 10 immigrants every 10 th year increased the probability of persistence to $100 \%$ for both the 250 -

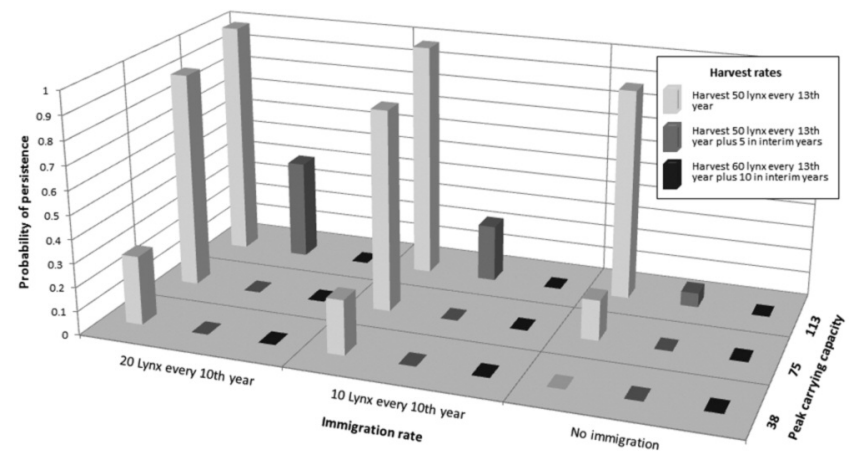

FIGURE 3. Probability of 50-year persistence of a population of Canada Lynx (Lynx canadensis) under a range of immigration rates, peak carrying capacities, and harvest rates.

TABLE 3. Population viability (250-year) of Canada Lynx (Lynx canadensis) on Isle Royale based on various non-harvest scenarios.

\begin{tabular}{|c|c|c|c|c|c|}
\hline Scenario & $\begin{array}{l}\text { Probability } \\
\text { of persistence }\end{array}$ & $\begin{array}{l}\text { Mean no. } \\
\text { years of } \\
\text { extinct runs } \\
\text { (SD) }\end{array}$ & $\begin{array}{c}\text { Mean final } \\
\text { population } \\
\text { size, extant } \\
\text { runs (SD) }\end{array}$ & $\begin{array}{l}\text { Final no. } \\
\text { alleles* }\end{array}$ & $\begin{array}{c}\text { Final } \\
\text { expected } \\
\text { heterozygosity }\end{array}$ \\
\hline $\begin{array}{l}\text { 10-year cyclical population with peak carrying } \\
\text { capacity of } 75 \text { lynx and inbreeding (baseline) }\end{array}$ & 0.136 & $197.0(36.1)$ & $12.8(13.4)$ & 1.70 & 0.239 \\
\hline Assuming a non-cyclical population & 0.417 & $207.6(32.7)$ & $19.7(15.1)$ & 2.01 & 0.321 \\
\hline Peak carrying capacity of 38 lynx & 0.000 & $72.6(26.8)$ & na & na & na \\
\hline Peak carrying capacity of 113 lynx & 0.941 & $226.0(24.9)$ & $64.4(27.8)$ & 3.26 & 0.510 \\
\hline Assuming no inbreeding depression & 1.000 & na & $68.6(8.8)$ & 2.39 & 0.377 \\
\hline Assuming 10 immigrants every 10 th year & 1.000 & na & $70.1(8.7)$ & 37.41 & 0.926 \\
\hline
\end{tabular}

*Using the VORTEX default infinite allele model.

Note: $\mathrm{na}=$ not applicable; $\mathrm{SD}=$ standard deviation. 
year (Table 3) and 1000-year simulations even when inbreeding was enabled.

\section{Quantitative analysis of changes in connectivity}

The number of days each winter with $\geq 90 \%$ ice concentration between the mainland and Isle Royale declined significantly $(P<0.01)$ at a rate of $4.5 \%$ annually from a modeled 56 days in 1973 to 10 days in 2011 (Figure 4). Based on the Isle Royale Wolf-Moose
Project binomial observations, the probability of an ice bridge forming in 1958-59 was 0.78 whereas in 2012-13 it was 0.10 , a significant decline $(P<0.01$ : Figure 5). The Duluth Harbor station showed a significant $(P<0.01)$ annual decline of $0.6 \%$ in ice thickness over 1900-70 (Figure 6) whereas the Two Harbors and Keweenaw datasets each showed a $0.2 \%$ annual decline over the same period $(P>0.05)$.

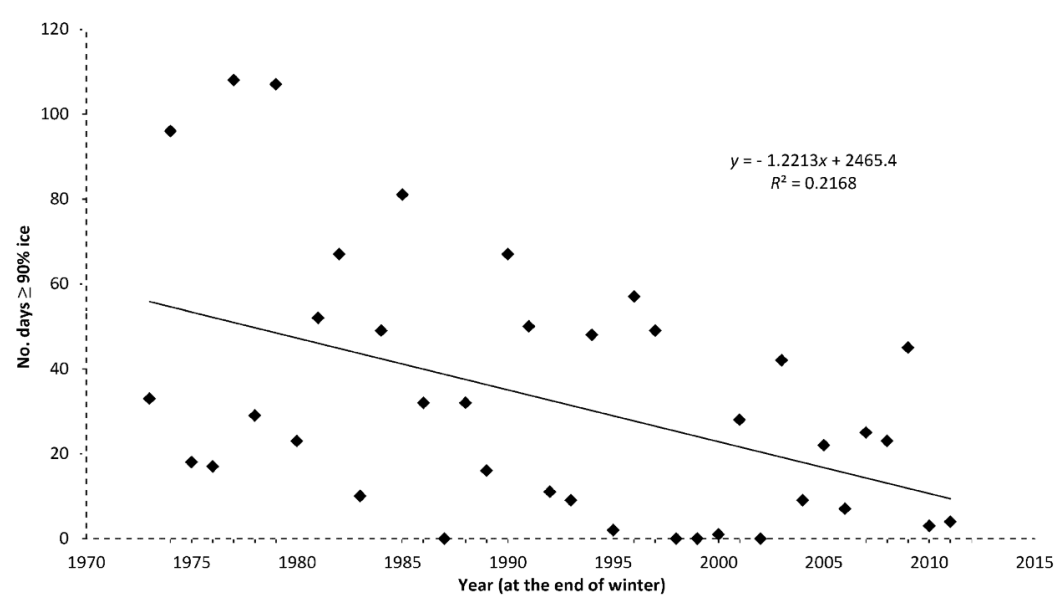

FIGURE 4. Number of days with ice concentration $\geq 90 \%$ between Isle Royale and the Minnesota-Ontario shoreline and linear regression trend. Source: Assel (2014*).

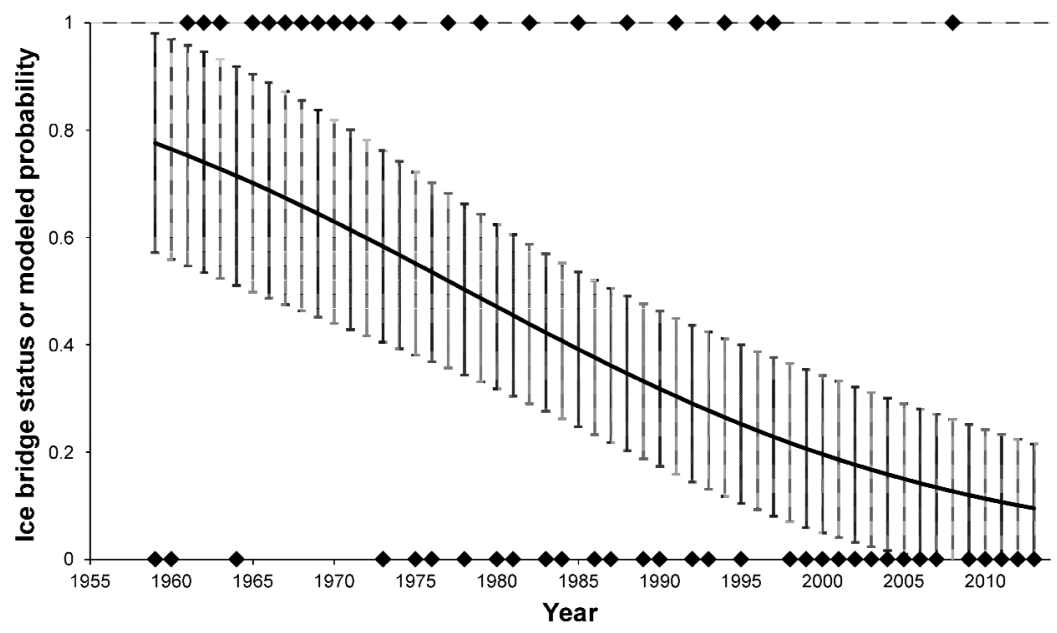

FIGURE 5 . Observed $(1=$ yes, $0=$ no $)$ and logistic regression probability of ice-bridge formation based on visual observations. Error bars are approximate $95 \%$ point-wise prediction intervals. Source: Wolf-Moose Project (2013*) and R. Peterson (personal communication, 2014). 


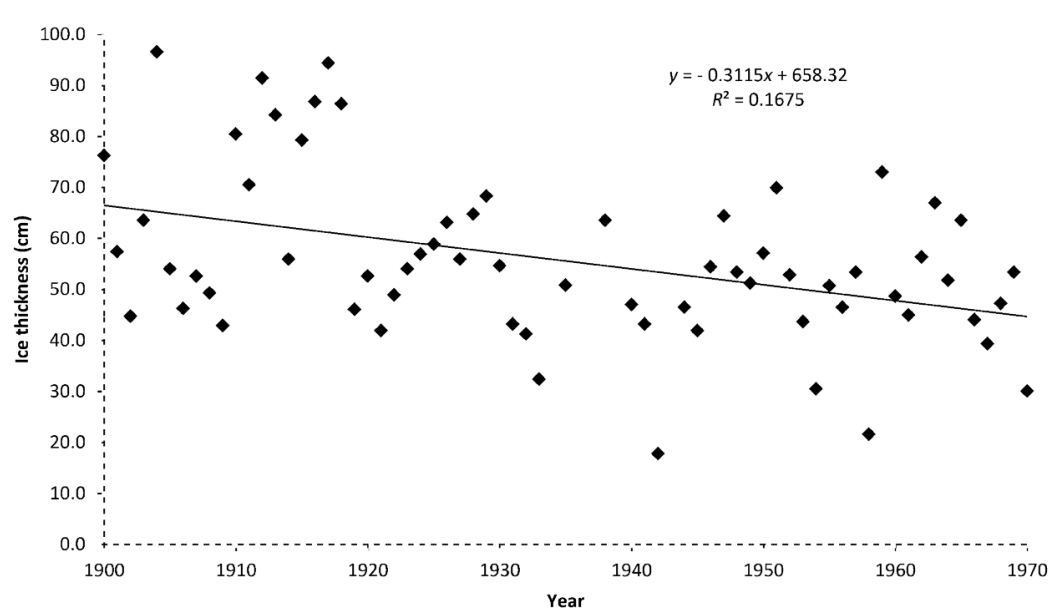

FIgURE 6. February-April ice thickness at Duluth Harbor, Minnesota, 1900-1970. Source: Assel (2004).

\section{Discussion}

The reasons for the extirpation of Canada Lynx from Isle Royale may never be fully understood, but, if the historical harvest records are accurate, then over-harvest alone could have caused the extirpation. Lynx populations are susceptible to over-harvest (Bailey et al. 1986; Slough and Mowat 1996), and such mortality is added to natural mortality (Brand and Keith 1979; Anderson and Lovallo 2003). Bailey et al. (1986) found that $80 \%$ of the marked lynx at their study site in Alaska were trapped within a year and Parker et al. (1983) estimated that $65 \%$ of their study population in Nova Scotia was removed by trapping. The idea that overharvest caused the extirpation of lynx from Isle Royale has been suggested by others although no quantitative analysis appears to have been conducted. Mech (1966: 16) stated that people are "probably responsible for exterminating the Lynx." Martin (1988: 2) stated that "lynxes, like marten, were heavily trapped throughout the region during the early $1900 \mathrm{~s}$. Once the dominant predator on Isle Royale, they were extirpated in the 1930s after no less than four decades of systematic trapping."

Our analyses of the long-term viability of Canada Lynx on Isle Royale - even in the absence of harvest - indicate that the population needed immigrants to lessen the impact of inbreeding depression. Regular historical lynx immigration to Isle Royale is plausible. Both Schwartz et al. (2002) and Row et al. (2012) found high gene flow between lynx populations, even those separated by great distances. Dispersal of lynx appears to be substantial during the post-peak decline in the 8-11 year population cycle, with many animals traveling more than $100 \mathrm{~km}$ (Slough and Mowat 1996; Poole 1997). During lows in the Snowshoe Hare population cycle, large numbers of lynx may move southward into northern Minnesota in what has been termed an "invasion" (Mech 1973; Gunderson 1978; Henderson 1978). Dispersing lynx have been documented venturing hundreds of kilometres into treeless habitats and crossing frozen lakes (Mech 1973; Gunderson 1978; Ward and Krebs 1985; Devineau et al. 2010). Cochrane (2013) reported that ice-bridge formation was so substantial between Isle Royale and the mainland in the 1870 s that draft horses and dog teams regularly crossed the ice. Thus, it is conceivable, even likely, that lynx historically crossed a $22-\mathrm{km}$ ice bridge between the mainland and Isle Royale and, as a result, the population persisted for a long time. So why did immigration cease and why have lynx not recolonized the island?

The extirpation of lynx at Isle Royale occurred at a time when lynx populations were declining throughout the Great Lakes region due, in part, to unregulated harvest (Johnson 1922; de Vos and Matel 1952). The population decline and range contraction of mainland lynx may have reduced or eliminated immigration to Isle Royale during the period from 1930 to the 1960s. At the same time, changes in ice-bridge formation were occurring.

Our three ice-bridge analyses showed that the frequency of formation of an ice bridge between Isle Royale and the mainland is declining. Our results are corroborated by other studies of Great Lakes ice cover (Magnuson et al. 2000; Assel 2003; Wang et al. 2012). Assel (1990) showed that the decline in ice formation may have started in the late 19th century. More recently, the NOAA (2009) reported that densely packed ice near Great Lakes shores had declined about 20\% from 1973-2002 and that Lake Superior has shown the greatest decrease in total ice cover of all the Great Lakes over the past several decades. Vucetich and Peterson (2011) reported that ice bridges between Isle Royale and the mainland have formed in only 2 of the past 15 years and one of those years was the only 
known instance of a wolf immigrating to the island since the 1940s. Vucetich et al. (2012) suggested that the decreasing frequency of an ice bridge, along with anthropogenic development along the Lake Superior shoreline (e.g., the Trans-Canada Highway and expansion of the city of Thunder Bay, Ontario) has significantly reduced the likelihood of wolf immigration to the island. Conversely, Mech (2013) suggested that climate change may not lead to a reduction in ice-bridge formation and, hence, there was no need to transplant wolves to the island for genetic augmentation; however, our analyses and corroborating evidence by others (Magnuson et al. 2000; Assel 2003; Wang et al. 2012) strongly indicate that the frequency of ice-bridge formation between Isle Royale and the mainland is declining due to climate change.

Climate change is widely identified as one of the major threats facing wildlife populations (Thomas et al. 2004). In Canada, climate change may disproportionately affect large-bodied mammals more than smaller ones (Imre and Derbowka 2011). The impacts on wildlife are generally thought to be via changes in plant communities, altered phenology, physiological stresses, changes in disease patterns, and escalating catastrophic weather events, among other factors (Gitay et al. 2002; Geyer et al. 2011; Nichols et al. 2011). The Interagency Lynx Biology Team (2013) categorized climate change impacts on lynx as shifts in distribution, changes in periodicity of the Snowshoe Hare cycle, reduction in lynx habitat and population size, changes in demographic rates, and changes in predator-prey relationships. Carroll (2007) and Gonzalez et al. (2007) speculated that climate change will decrease snow cover and reduce and degrade boreal habitat, resulting in local extirpations and range decline. We show that climate change can also reduce or eliminate metapopulation processes and contribute to local extirpations.

\section{Conclusion}

Our analyses suggest that Canada Lynx were extirpated from Isle Royale due to human activities and that over-harvest alone could have caused the extirpation. However, our analyses also suggest that climate change and the declining frequency of ice-bridge formation may prevent natural recolonization and reduce the viability of a future population, whether naturally recolonized or reintroduced by management. The Isle Royale situation exemplifies the notion that, as climate change reduces or eliminates connectivity, long-term conservation success may require periodic population augmentation to mitigate the loss of connectivity between populations.

\section{Acknowledgements}

We thank Rolf Peterson (Michigan Tech University) for allowing us to use the ice-bridge observations from the Isle Royale Wolf-Moose Study annual reports, his notes, and a helpful review of the document. Timothy Cochrane (Grand Portage National Monument, United
States National Park Service) provided important historical information.

\section{Documents Cited (marked * in text)}

Assel, R. A. 2014. NOAA atlas: an electronic atlas of Great Lakes ice cover: winters 1973-2002. National Oceanic and Atmospheric Administration, Great Lakes Environmental Research Laboratory, Ann Arbor, Michigan, USA. Accessed 9 January 2014. http://www.glerl.noaa.gov /data/ice/atlas.

Wolf-Moose Project. 2013. Wolves and moose of Isle Royale. Website of Michigan Technological University. Accessed 30 July 2013. http://isleroyalewolf.org/.

\section{Literature Cited}

Adams, C. C. 1909. An Ecological Survey of Isle Royale, Lake Superior. Wynkoop Hallenbeck Crawford Co., Lansing, Michigan, USA.

Allen, D. L. 1994. Wolves of Minong: Isle Royale's Wild Community. University of Michigan Press, Ann Arbor, Michigan, USA.

Anderson, E. M., and M. J. Lovallo. 2003. Bobcat and lynx (Lynx rufus and Lynx canadensis). Pages 758-788 in Wild Mammals of North America: Biology, Management, and Conservation. Edited by G. A. Feldhamer, B. C. Thompson, and J. A. Chapman. Second edition. The John Hopkins University Press, Baltimore, Maryland, USA.

Assel, R. A. 1990. An ice-cover climatology for Lake Erie and Lake Superior for the winter seasons 1897-1898 to 1982-1983. International Journal of Climatology 10: 731748.

Assel, R. A. 2003. Great Lakes ice cover, first ice, last ice, and ice duration: winters 1973-2002. National Oceanic and Atmospheric Administration Technical Memorandum GLERL-125. Great Lakes Environmental Research Laboratory, Ann Arbor, Michigan, USA.

Assel, R. A. 2004. Computerized National Weather Service Great Lakes ice reports for winter seasons 1899-1970. National Oceanic and Atmospheric Administration Technical Memorandum GLERL-130. Great Lakes Environmental Research Laboratory, Ann Arbor, Michigan, USA.

Assel, R. A., D. C. Norton, and K. C. Cronk. 2002. A Great Lakes digital ice cover data base for winters 1973-2000. National Oceanic and Atmospheric Administration Technical Memorandum GLERL-121. Great Lakes Environmental Research Laboratory, Ann Arbor, Michigan, USA.

Bailey, T. N., E. E. Bangs, M. F. Portner, J. C. Malloy, and R. J. McAvinchey. 1986. An apparent overexploited lynx population in the Kenai Peninsula, Alaska. Journal of Wildlife Management 50: 279-290.

Biek, R., R. L. Zarnke, C. Gillin, M. Wild, J. R. Squires, and M. Poss. 2002. Serologic survey for viral and bacterial infections in western populations of Canada Lynx (Lynx canadensis). Journal of Wildlife Diseases 38: 840-845.

Brand, C. J., and L. B. Keith. 1979. Lynx demography during a snowshoe hare decline in Alberta. Journal of Wildlife Management 43: 827-849.

Brand, C. J., L. B. Keith, and C. A. Fischer. 1976. Lynx responses to changing snowshoe hare densities in Central Alberta. Journal of Wildlife Management 40: 416-428.

Buskirk, S. W. 2000. Habitat fragmentation and interspecific competition: implications for lynx conservation. Pages 83100 in Ecology and Conservation of Lynx in the United States. Edited by L. F. Ruggiero, K. B. Aubry, S. W. Bus- 
kirk, G. M. Koehler, C. J. Krebs, K. S. McKelvey, and J. R. Squires. University Press of Colorado and the USDA Rocky Mountain Research Station, Fort Collins, Colorado.

Carroll, C. 2007. Interacting effects of climate change, landscape conversion, and harvest on carnivore populations at the range margin: marten and lynx in the Northern Appalachians. Conservation Biology 21: 1092-1104.

Cleland, C. E. 1966. The prehistoric animal ecology and ethnozoology of the Upper Great Lakes region. Anthropology Paper. University of Michigan Museum of Anthropology, Ann Arbor, Michigan, USA.

Cleland, C. E. 1968. Analysis of the fauna of the Indian Point site on Isle Royale in Lake Superior. Michigan Archaeologist 14: 143-146.

Cochrane, J. F. 1996. Woodland Caribou Restoration at Isle Royale National Park: A Feasibility Study. National Park Service, Denver, Colorado, USA.

Cochrane, T. 2013. Island complications: should we retain wolves on Isle Royale? George Wright Forum 30: 313-325.

Cole, K. L., R. L. Flakne, D. R. Engstrom, and D. E. Harlow. 1997. Three hundred years of vegetation change and fire history on Isle Royale, MI. Bulletin of the Ecological Society of America 78: 70.

Cooper, W. S. 1913. The climax forest of Isle Royale, Lake Superior, and its development. Botanical Gazette 55: 1-44.

Cully Jr., J. F., T. L. Johnson, S. K. Collinge, and C. Ray. 2010. Disease limits populations: plague and black-tailed prairie dogs. Vector Borne and Zoonotic Diseases 10: 7-15.

de Castro, F., and B. Bolker. 2005. Mechanisms of diseaseinduced extinction. Ecology Letters 8: 117-126.

de Vos, A., and S. E. Matel. 1952. The status of lynx in Canada, 1929-1952. Journal of Forestry 50: 742-745.

Descamps, S., S. Jenouvrier, H. G. Gilchrist, and M. R. Forbes. 2012. Avian cholera, a threat to the viability of an Arctic seabird colony? PLoS ONE 7: e29659.

Devineau, O., T. M. Shenk, G. C. White, P. F. Doherty, Jr., P. M. Lukacs, and R. H. Kahn. 2010. Evaluating the Canada Lynx reintroduction programme in Colorado: patterns in mortality. Journal of Applied Ecology 47: 524-531.

Dodds, D. G. 1960. Food competition and range relationships of moose and snowshoe hare in Newfoundland. Journal of Wildlife Management 24: 52-60.

Elton, C., and M. Nicholson. 1942. The ten-year cycle in numbers of the lynx in Canada. Journal of Animal Ecology 11: $215-244$.

Feierabend, D., and K. Kielland. 2014. Multiple crossings of a large glacial river by Canada Lynx (Lynx canadensis). Canadian Field-Naturalist 128: 80-83.

Foster, U. H. 1917. Review of wild life - Isle Royale 1916-1917. Michigan Sportsman 4: 16-18

Geyer, J., I. Kiefer, S. Kreft, V. Chavez, N. Salafsky, F. Jeltsch, and P. L. Ibisch. 2011. Classification of climatechanged induced stresses on biological diversity. Conservation Biology 25: 708-715.

Gitay, H., A. Suarez, R. T. Watson, and D. J. Dokken. 2002. Climate change and biodiversity. Technical Paper V. Intergovernmental Panel on Climate Change, Geneva, Switzerland.

Gonzalez, P., R. P. Neilson, K. S. McKelvey, J. M. Lenihan, and R. J. Drapek. 2007. Potential impacts of climate changes on habitat and conservation priority areas for Lynx canadensis (Canada Lynx). The Nature Conservancy, Washington, D.C., USA.

Gunderson, H. L. 1978. A mid-continent irruption of Canada Lynx, 1962-63. Prairie Naturalist 10: 71-80.
Henderson, C. 1978. The lynx link. The Minnesota Volunteer January-February: 16-21.

Hodges, K. E. 2000a. The ecology of snowshoe hares in northern boreal forests. Pages 117-162 in Ecology and Conservation of Lynx in the United States. Edited by L. F. Ruggiero, K. B. Aubry, S. W. Buskirk, G. M. Koehler, C. J. Krebs, K. S. McKelvey, and J. R. Squires. University Press of Colorado and the United States Department of Agriculture Rocky Mountain Research Station, Fort Collins, Colorado, USA.

Hodges, K. E. 2000b. The ecology of snowshoe hares in southern boreal and montane forests. Pages 163-206 in Ecology and Conservation of Lynx in the United States. Edited by L. F. Ruggiero, K. B. Aubry, S. W. Buskirk, G. M. Koehler, C. J. Krebs, K. S. McKelvey, and J. R. Squires. University Press of Colorado and the United States Department of Agriculture Rocky Mountain Research Station, Fort Collins, Colorado, USA.

Imre, I., and D. Derbowka. 2011. Major threats facing terrestrial mammals in Canada. Canadian Field-Naturalist 125: 213-219.

Interagency Lynx Biology Team. 2013. Canada Lynx Conservation Assessment and Strategy. 3rd edition. Forest Service publication R1-13-19. United States Department of Agriculture Forest Service, United States Department of the Interior (USDI) Fish and Wildlife Service, USDI Bureau of Land Management, and USDI National Park Service, Missoula, Montana, USA.

Johnson, C. E. 1922. Notes on the mammals of northern Lake County, Minnesota. Journal of Mammalogy 3: 33-39.

Johnson, W. J. 1969. Food Habits of the Isle Royale Red Fox and Population Aspects of Three of Its Principal Prey Species. Ph.D. thesis, Purdue University, West Lafayette, Indiana, USA.

Johnsson, R. G., P. C. Shelton, and P. A. Jordan. 1982. Wildlife of Isle Royale: Check Lists of All Vertebrate Animals Known at Isle Royale Including Their Current Status. Isle Royale Natural History Association, Houghton, Michigan, USA.

Kobalenko, J. 1997. Forest Cats of North America: Cougars, Bobcats, and Lynx. Firefly Books, Willowdale, Ontario, Canada.

Koen, E. L., J. Bowman, D. L. Murray, and P. J. Wilson. 2014. Climate change reduces genetic diversity of Canada Lynx at the trailing range edge. Ecography 37: 754-762.

Krebs, C. J., R. Boonstra, S. Boutin, and A. R. E. Sinclair. 2001. What drives the 10-year cycle of Snowshoe Hares? BioScience 51: 25-35.

Krefting, L. W. 1969. The rise and fall of the coyote on Isle Royale. Michigan Naturalist 20: 24-31.

Krefting, L. W. 1974. The ecology of the Isle Royale moose with special reference to the habitat. Report 297. University of Minnesota, Agricultural Experiment Station, St. Paul, Minnesota, USA.

Lacy, R. C., P. S. Miller, and K. Traylor-Holzer. 2014. Vortex 10 Users' Manual. International Union for Conservation of Nature Species Survival Commission Conservation Breeding Specialist Group and Chicago Zoological Society, Apple Valley, Minnesota, USA.

Lacy, R. C., and J. P. Pollak. 2014.Vortex: A Stochastic Stimulation of the Ecological Process. Version 10.0. Chicago Zoological Society, Brookfield, Illinois, USA.

Laliberte, A. S., and W. J. Ripple. 2004. Range contractions of North American carnivores and ungulates. BioScience 54: $123-138$. 
MacKinnon, C. M., and A. C. Kennedy. 2008. Canada Lynx, Lynx canadensis, use of the Chignecto Isthmus and the possibility of gene flow between populations in New Brunswick and Nova Scotia. Canadian Field-Naturalist 122: 166168.

Magnuson, J. J., D. M. Robertson, B. J. Benson, R. H. Wynne, D. M. Livingstone, T. Arai, R. A. Assel, R. G. Barry, V. Card, E. Kuusisto, N. G. Granin, T. D. Prowse, K. M. Stewart, and V. S. Vuglinski. 2000. Historical trends in lake and river ice cover in the Northern Hemisphere. Science 289: 1743-1746.

Martin, C. 1988. The history and reestablishment potential of marten, lynx, and woodland caribou on Isle Royale. Resource Management Report 88-2, National Park Service, Houghton, Michigan, USA.

McKelvey, K. S. 2000. History and distribution of lynx in the contiguous United States. Pages 207-264 in Ecology and Conservation of Lynx in the United States. Edited by L. F. Ruggiero, K. B. Aubry, S. W. Buskirk, G. M. Koehler, C. J. Krebs, K. S. McKelvey, and J. R. Squires. University Press of Colorado and the United States Department of Agriculture Rocky Mountain Research Station, Fort Collins, Colorado, USA.

Mech, L. D. 1966. The wolves of Isle Royale. Faunal Series 7, National Park Service, Washington, D.C., USA.

Mech, L. D. 1973. Canadian lynx invasion of Minnesota. Biological Conservation 5: 151-152.

Mech, L. D. 1980. Age, sex, reproduction, and spatial organization of lynxes colonizing northeastern Minnesota. Journal of Mammalogy 61: 261-267.

Mech, L. D. 2013. The case for watchful waiting with Isle Royale's wolf population. George Wright Forum 30: 326 332.

Miller, P. S., and R. C. Lacy. 2005. VORTEX: A stochastic simulation of the extinction process. Version 9.50 User's Manual. International Union for the Conservation of Nature., Apple Valley, Minnesota, USA.

Moen, R., G. Niemi, and C. L. Burdett. 2008. Canada Lynx in the Great Lakes Region: final report to the USDA Forest Service and U.S. Geological Survey and Minnesota Department of Natural Resources. University of Minnesota, Duluth, Duluth, Minnesota, USA.

Murie, A. 1934. The moose of Isle Royale. University of Michigan, Ann Arbor, Michigan, USA.

Murray, D. L., T. D. Steury, and J. D. Roth. 2008. Assessment ofCanada Lynx research and conservation needs in the southern range: another kick at the cat. Journal of Wildlife Management 72: 1463-1472.

The Nature Conservancy. 1999. USGS-NPS vegetation mapping program: classification of the vegetation of Isle Royale National Park, September 9, 1999. The Nature Conservancy, Minneapolis, Minnesota, USA.

NPS (National Park Service). 1998. Isle Royale general management plan. NPS, Houghton, Michigan, USA

NPS (National Park Service). 2006. Management policies: the guide to managing the National Park System. NPS, Washington, D.C., USA.

Nichols, J. D., M. D. Koneff, P. J. Heglund, M. G. Knutson, M. E. Seamans, J. E. Lyons, J. M. Morton, M. T. Jones, G. S. Boomer, and B. K. Williams. 2011. Climate change, uncertainty, and natural resource management. Journal of Wildlife Management 75: 6-18.

NOAA (National Oceanic and Atmospheric Administration). 2009. Ice cover on the Great Lakes. Great Lakes
Environmental Research Laboratory, Ann Arbor, Michigan, USA.

O'Donoghue, M. O., B. G. Slough, K. G. Poole, S. Boutin, E. J. Hofer, G. Mowat, and C. J. Krebs. 2010. Cyclical dynamics and behaviour of Canada Lynx in northern Canada. Pages 521-536 in The Biology and Conservation of Wild Felids. Edited by D. Macdonald and A. Loveridge. Oxford University Press, New York, New York, USA.

O'Donoghue, M., S. Boutin, C. J. Krebs, and E. J. Hofer. 1997. Numerical responses of coyotes and lynx to the snowshoe hare cycle. Oikos 80: 150-162.

O'Donoghue, M., S. Boutin, C. J. Krebs, G. Zuleta, D. L. Murray, and E. J. Hofer. 1998. Functional responses of coyotes and lynx to the snowshoe hare cycle. Ecology 79 : 1193-1208.

Oldemeyer, J. L. 1983. Browse production and its use by moose and snowshoe hares at the Kenai Moose Research Center, Alaska. Journal of Wildlife Management 47: 486496.

Palliser, J. 1863. Exploration - British North America: the journals, detailed reports; and observations relative to Captail Palliser's exploration of a portion of British North America, which, in latitude, lies between the British boundary line and the height of land or watershed of the northern or frozen ocean respectively, and in longitude, between the western shore of Lake Superior and the Pacific Ocean during the years 1857, 1858, 1859, and 1860. G. E. Eyre and W. Spottiswoode, London, U.K.

Parker, G. R., J. W. Maxwell, L. D. Morton, and G. E. J. Smith. 1983. The ecology of lynx (Lynx canadensis) on Cape Breton Island. Canadian Journal of Zoology 61: 770-786.

Peterson, R. O., N. J. Thomas, J. M. Thurber, J. A. Vucetich, and T. A. Waite. 1998. Population limitation and the wolves of Isle Royale. Journal of Mammalogy 79: $828-841$

Poole, K. G. 1991. Lynx research in the NWT, 1990-91. Manuscript report 52. Government of the Northwest Territories, Yellowknife, Northwest Territories, Canada.

Poole, K. G. 1994. Characteristics of an unharvested lynx population during a snowshoe hare decline. Journal of Wildlife Management 58: 608-618.

Poole, K. G. 1997. Dispersal patterns of lynx in the Northwest Territories. Journal of Wildlife Management 61: 497-505.

Poole, K. G. 2003. A review of the Canada Lynx, Lynx canadensis, in Canada. Canadian Field-Naturalist 117: 360-376.

Quinn, N. W. S., and J. E. Thompson. 1987. Dynamics of an exploited Canada Lynx population in Ontario. Journal of Wildlife Management 51: 297-305.

Ranta, E., V. Kaitala, and P. Lundberg. 1997. The spatial dimension in population fluctuations. Science 278: 16211623.

Row, J. R., C. Gomez, E. L. Koen, J. Bowman, D. L. Murray, and P. J. Wilson. 2012. Dispersal promotes high gene flow among Canada Lynx populations across mainland North America. Conservation Genetics 13: 1259-1268.

Ruggiero, L. F., and K. S. McKelvey. 2000. Toward a defensible lynx conservation strategy: a framework for planning in the face of uncertainty. Pages 5-19 in Ecology and Conservation of Lynx in the United States. Edited by L. F. Ruggiero, K. B. Aubry, S. W. Buskirk, G. M. Koehler, C. J. Krebs, K. S. McKelvey, and J. R. Squires. University Press of Colorado and the United States Department of Agriculture, Rocky Mountain Research Station, Fort Collins, Colorado, USA. 
Ryser-Degiorgis, M.-P., R. Hofmann-Lehmann, C. M. Leutenegger, C. H. af Segerstand, T. Mörner, R. Mattsson, and H. Lutz. 2005. Epizootiologic investigations of selected infectious disease agents in free-ranging Eurasian lynx from Sweden. Journal of Wildlife Diseases 41: 58-66.

Saunders, Jr., J. K. 1963. Food habits of the lynx in Newfoundland. Journal of Wildlife Management 27: 384-390.

Schwartz, M. K., L. S. Mills, K. S. McKelvey, L. F. Ruggiero, and F. W. Allendorf. 2002. DNA reveals high dispersal synchronizing the population dynamics of Canada Lynx. Nature 415: 520-522.

Scott, W. P. 1925. Reminiscences of Isle Royale. Michigan History 9: 398-412.

Shelton, N. 1997. Superior Wilderness: Isle Royale National Park. Isle Royale Natural History Association, Houghton, Michigan, USA.

Slough, B. G., and G. Mowat. 1996. Lynx population dynamics in an untrapped refugium. Journal of Wildlife Management 60: 946-961.

Snyder, J. D., and R. A. Janke. 1976. Impact of moose browsing on boreal-type forests of Isle Royale National Park. American Midland Naturalist 95: 79-92.

Stenseth, N. C., K.-S. Chan, H. Tong, R. Boonstra, S. Boutin, C. J. Krebs, E. Post, M. O'Donoghue, N. G. Yoccoz, M. C. Forchhammer, and J. W. Hurrell. 1999. Common dynamic structure of Canada Lynx populations within three climatic regions. Science 285: 1071-1073.

Steury, T. D., and D. L. Murray. 2004. Modeling the reintroduction of lynx to the southern portion of its range. Biological Conservation 117: 127-141.

Thomas, C. D., A. Cameron, R. E. Green, M. Bakkenes, L. J. Beaumont, Y. C. Collingham, B. F. N. Erasmus, M. F. de Siqueira, A. Grainger, L. Hannah, L. Hughes,
B. Huntley, A. S. van Jaarsveld, G. F. Midgley, L. Miles, M. A. Ortega-Huerta, A. T. Peterson, O. L. Phillips, and S. E. Williams. 2004. Extinction risk from climate change. Nature 427: 145-148.

United States Fish and Wildlife Service. 2000. Determination of threatened status for the contiguous United States distinct population segment of the Canada Lynx and related rule; final rule. Federal Register. 50 CFR Part 17. 1605216086. March 24, 2000.

Vashon, J., S. McLellan, S. Crowley, A. Meehan, and K. Laustsen. 2012. Canada Lynx assessment. Maine Department of Inland Fisheries and Wildlife, Bangor, Maine, USA.

Vucetich, J. A., M. P. Nelson, and R. O. Peterson. 2012. Should Isle Royale wolves be reintroduced? A case study on wilderness management in a changing world. The George Wright Forum 29: 126-147.

Vucetich, J. A., and R. O. Peterson. 2011. Ecological studies of wolves on Isle Royale: annual report 2010-2011. Michigan Technological University, Houghton, Michigan, USA.

Wang, J., X. Bai, H. Hu, A. Clites, M. Colton, and B. Lofgren. 2012. Temporal and spatial variability of Great Lakes ice cover, 1973-2010. Journal of Climate 25: 1318-1329.

Ward, R. P. M., and C. J. Krebs. 1985. Behavioural responses of lynx to declining snowshoe hare abundance. Canadian Journal of Zoology 63: 2817-2824.

Wild, M. A., T. M. Shenk, and T. R. Spraker. 2006. Plague as a mortality factor in Canada Lynx (Lynx canadensis) reintroduced to Colorado. Journal of Wildlife Diseases 42: 646-650.

Received 7 March 2014

Accepted 4 February 2015 